\title{
Konsentrasi Paraquat dalam Urin Pekerja Akibat Paparan Paraquat di Perkebunan Kelapa Sawit
}

\author{
Paraquat Concentration in Urin Workers Due to Paraquat \\ Exposure in Palm Oil Plantation
}

\author{
Maksuk \\ Poltekkes Kemenkes Palembang \\ (maksuk@poltekkespalembang.ac.id)
}

\begin{abstract}
ABSTRAK
Paraquat merupakan herbisida yang sangat toksik terutama yang masuk ke dalam tubuh manusia melalui rute ingesti, inhalasi dan kulit. Penelitian ini bertujuan untuk menganalisis konsentrasi paraquat dalam urin pekerja akibat paparan paraquat di perkebunan kelapa sawit. Desain studi potong lintang, dengan jumlah sampel sebanyak 60 responden dan dipilih secara acak. Urin dikumpulkan pada hari terakhir penyemprotan paraquat dan merupakan urin sewaktu. Pemeriksaan konsentrasi paraquat dalam urin pekerja dilakukan di laboratorium menggunakan High Performance Liquid Chromatography (HPLC) dengan metode EPA 549.2. Data dianalisis dengan cara univariat dan bivariat menggunakan uji Mann Whitney. Konsentrasi paraquat dalam urin pekerja ditemukan pada pekerja pria dengan rerata yaitu $6,35 \mathrm{mg} / \mathrm{L}$ dan wanita $6,55 \mathrm{mg} / \mathrm{L}$, dengan kisaran antara $0,25-35,75 \mathrm{mg} / \mathrm{L}$, tetapi hasil ini tidak dapat dibandingkan dengan nilai indeks pemantaun biologi karena belum ada batasan yang ditetapkan baik secara nasional maupun internasional. Hasil uji Mann Whitney menunjukkan bahwa konsentrasi paraquat dalam urin pekerja dipengaruhi oleh beberapa variabel yaitu lama kerja $(p=0,026)$, metode penyemprotan $(p=0,048)$, makan/minum saat aplikasi $(p=0,040)$, kelengkapan penggunaan alat pelindung diri $(p=0,03)$ dan dekontaminasi setelah terpapar paraquat $(\mathrm{p}=0,026)$. Penelitian ini memberikan bukti mengenai keberadaan paraquat dalam urin pekerja, yang seharusnya paraquat tidak berada dalam tubuh pekerja. Oleh karena itu, perlu dilakukan biomonitoring secara berkala untuk konsentrasi paraquat dalam urin pekerja terutama yang melakukan aplikasi penyemprotan paraquat.
\end{abstract}

Kata kunci : Paparan paraquat, konsentrasi paraquat urin, perkebunan sawit

\section{ABSTRACT}

Paraquat is an active ingredient of herbicide, it is very toxic mainly in humans and can enter the body through ingestion, inhalation and skin. This study aimed to analyze paraquat exposure to paraquat concentrations in the urine of workers on palm oil plantations. This study used a cross sectional design, with a sample of 60 workers and randomly selected, urine was collected on the last day of paraquat spraying. Paraquat in urine was tested in a laboratory using High Performance Liquid Chromatography (HPLC) using the EPA 549.2 methods. Data were analyzed by univariate and bivariate using Mann Whitney test.The average of paraquat concentration in urine of men workers was $6.35 \mathrm{mg} / \mathrm{L}$ and women $6.55 \mathrm{mg} / \mathrm{L}$, with a range between $<0.25-35.75 \mathrm{mg} / \mathrm{L}$. The results of Mann Whitney test showed that the difference of paraquat concentration in urine of workers was influenced by several variables, namely length of work ( $p=0.026)$, spraying method $(p=0.048)$, eating / drinking during application $(p=0.040)$, completeness of using personal protection equipment $(p=0.03)$ and decontamination after spraying ( $p=0.026)$. This study provided evidence of paraquat presence in urine workers'. Therefore it is necessary to urine examination periodically.

Keywords : Paraquat exposure, paraquat concentration in urine, palm oil plantation 


\section{PENDAHULUAN}

Penggunaan pestisida di area pertanian maupun perkebunan saat ini semakin meningkat terutama di negara-negara berkembang termasuk Indonesia. Saat ini jumlah pestisida yang digunakan dan terdaftar sebanyak 3.207 formulasi untuk pertanian dan perkebunan. ${ }^{1}$ Herbisida merupakan jenis pestisida yang banyak digunakan di area pertanian dan perkebunan, penggunaanya sekitar $50-60 \%,{ }^{2}$ bahan aktif herbisida yang banyak digunakan, yaitu paraquat diklorida. ${ }^{3}$

Paraquat (1,1-dimetil,4,4bipiridilium) merupakan salah satu bahan aktif herbisida yang toksik dan diklasifikasikan sebagai hazard kategori II. ${ }^{4}$ Oleh karena itu, penggunaan paraquat di beberapa negara telah dibatasi, ${ }^{5}$ termasuk di Indonesia. ${ }^{6}$ Di negara-negara berkembang seperti hal-nya Indonesia, paraquat digunakan secara bebas tanpa pengawasan secara ketat baik oleh pemerintah, swasta maupun produsen pestisida dan masih dengan mudah diperoleh dipasaran. Hal ini menyebabkan keterpaparan pekerja terhadap paraquat cukup tinggi terutama pada penyemprot dan pengawas selama penyemprotan di area perkebunan. $^{?}$

Paparan pekerja dengan paraquat tidak hanya menimbulkan gangguan kesehatan, tetapi juga dapat menyebabkan kematian karena daya racunnya sangat tinggi, dengan angka kematian sekitar 70-80\%. ${ }^{8}$ Paparan paraquat secara terus-menerus menyebabkan keracunan berat di Perancis, ${ }^{9}$ bahkan kejang pada pasien akibat konsentrasi paraquat dalam darah dan urin tinggi..$^{10}$ Paraquat yang tertelan dan diabsorbsi secara sistemik menyebabkan nekrosis hepatik akut dan penyakit ginjal sebanyak $20 \%,{ }^{11}$ dan juga menimbulkan gejala-gejala penyakit Parkinson. ${ }^{11,13}$

Selain itu proses metabolisme paraquat dalam tubuh dipengaruhi siklus redoks dan bersifat sangat reaktif menyebabkan terbentuknya radikal bebas seperti superoksid, hidrogen peroksida, hidroksil yang dapat merusak lemak, protein dan DNA. ${ }^{14,15}$ Paraquat juga diindikasikan menimbulkan efek neurodegenerasi akibat stres oksidatif dan formasi radikal bebas, ${ }^{16-19}$ akibat proses metabolisme dalam tubuh menyebabkan kerusakan jaringan dan multi organ dan menimbulkan gejala keracunan. ${ }^{20}$

Metabolisme paraquat dalam tubuh menye- babkan akumulasi di beberapa target organ diantaranya hati, jantung, ginjal dan organ lainnya melalui rute inhalasi, ingesti, kulit, rute tersebut paling sering dialami pekerja termasuk di perkebunan sawit yang dikenal dengan dosis potensial. ${ }^{21}$ Hasil penelitian di perkebunan sawit Kabupaten Banyuasin pada pekerja penyemprot paraquat dilaporkan bahwa dosis potensial melalui rute ingesti sebesar $0,00035 \mathrm{mg} / \mathrm{kg} / \mathrm{hr},{ }^{22}$ dan dosis potensial melalui rute inhalasi sebesar $0,001 \mathrm{mg} / \mathrm{kg} / \mathrm{hr},{ }^{23} \mathrm{se}-$ dangkan di perkebunan Malaysia juga ditemukan sebesar $0,025 \mathrm{mg} / \mathrm{kg} / \mathrm{hr}^{24}$

Paraquat dapat didistribusikan secara cepat dalam tubuh dan dieliminasi melalui urin dalam bentuk yang tidak diubah. ${ }^{25}$ Studi di perkebunan kopi konsentrasi paraquat dalam urin ditemukan rata-rata $5,74 \mathrm{mg} / \mathrm{L}$; di perkebunan pisang sebesar $11,39 \mathrm{mg} / \mathrm{L}$; di perkebunan kelapa sawit sebesar $2,19 \mathrm{mg} / \mathrm{L} .{ }^{26}$ Diperkebunan pisang paraquat dalam urin penyemprot ditemukan sebesar $<0,03 \mathrm{mg} / \mathrm{L}$ dan $0,24 \mathrm{mg} / \mathrm{L} ;{ }^{27}$ di Sri Lanka konsentrasi paraquat dalam urin penyemprot antara $<0,1-0,37 \mu \mathrm{g} /$ $\mathrm{mL} .{ }^{28}$ Di Amerika Serikat pekerja aplikasi paraquat lebih dari 12 minggu konsentrasi paraquat dalam urin ditemukan antara $0,15-0,32 \mathrm{mg} / \mathrm{L}^{29}$ Selain itu, konsentrasi paraquat dalam urin juga ditemukan pada ibu yang tinggal disekitar area pertanian Thailand, yaitu pada ibu dengan kehamilan 28 minggu, ibu bersalin dan 2 bulan setelah melahirkan masing-masing adalah 2,04, 2,06 dan $2,42 \mathrm{ng} / \mathrm{mL} .{ }^{30}$

Dari beberapa penelitian tersebut konsentrasi paraquat dalam urin tidak hanya ditemukan pada pekerja yang melakukan penyemprotan paraquat, tetapi juga ditemukan pada ibu yang tinggal di sekitar area pertanian. Berdasarkan fakta yang telah diuraikan, penelitian ini bertujuan untuk menganalisis konsentrasi paraquat dalam urin pekerja akibat paparan paraquat dan faktor yang mempengaruhinya di perkebunan kelapa sawit.

\section{BAHAN DAN METODE}

Bahan dan alat yang digunakan untuk pengambilan sampel urin yaitu sarung tangan, masker, pot urin, cool box, kertas label dan spidol. Penelitian ini merupakan penelitian observasional analitik dengan rancangan potong lintang. Pengambilan data dilakukan pada bulan Februari 2016 di perkebunan kelapa sawit Kabupaten 
Banyuasin. Populasi dalam penelitian ini sebanyak 105 pekerja dan yang menjadi sampel adalah pengawas dan penyemprot paraquat, perhitungan besar sampel dalam penelitian ini sebagai berikut: ${ }^{31}$

$$
\begin{aligned}
\mathrm{n} & =\left[\frac{\mathrm{Z} \times \mathrm{XS}}{\mathrm{d}}\right]^{2} \\
& =\left[\frac{(1,96) \times(3,7)}{1}\right]^{2}=52,6
\end{aligned}
$$

Keterangan : $\mathrm{n}=$ jumlah sampel; $\mathrm{Z} \alpha=$ deviat baku alfa; $\mathrm{S}=$ simpangan baku variabel yang diteliti; $\mathrm{d}=$ presisi. Untuk menghindari drop out sampel maka dibulatkan menjadi 60 sampel.

Pengambilan sampel dilakukan secara acak, sampel adalah urin sesaat yang pada hari terakhir penyemprotan. Prosedur pengambilan sampel urin yaitu urin ditampung dalam pot yang telah diberi label minimal $50 \mathrm{ml}$ yang diambil diakhir penyemprotan dan dimasukkan ke dalam cool box. Sebelum dikirim ke laboratorium urin disimpan dalam lemari pendingin. Selanjutnya urin diperiksa di laboratorium Anugrah Analisis Sempurna menggunakan High Performance Liquid Chromatograf (HPLC) dengan metode EPA 549.2. Analisis data dilakukan dengan cara univariat yaitu menyajikan data menggunakan tabel dan bivariat menggunakan uji Mann Whitney. ${ }^{32}$

\section{HASIL}

Total pekerja yang terlibat dalam pemeriksaan konsentrasi paraquat dalam urin sebanyak 60 pekerja. Hasil pemeriksaan konsenterasi paraquat dalam urin ditemukan antara $0,25-35,75 \mathrm{mg} / \mathrm{L}$. Data hasil pemeriksaan konsentrasi paraquat dalam urin pekerja selengkapnya dapat dilihat pada Tabel 1.

Pekerja yang terlibat dalam penelitian ini yaitu 60 pekerja, mayoritas pekerja berumur $\geq 34$ tahun sebanyak 37 pekerja $(61,7 \%)$, wanita sebanyak 37 pekerja $(61,7 \%)$, dan tingkat pendidikan rendah sebanyak 43 pekerja $(71,7 \%)$, sedangkan yang bekerja lebih dari 2 tahun sebanyak 33 (55\%). Indeks Masa Tubuh pekerja masih dikategorikan normal. Pekerja yang bekerja lebih dari 5 jam/hari sebanyak 36 pekerja $(60 \%)$ dengan aktivitas sebagai penyemprot sebanyak 45 pekerja (75\%). Data hasil analisis deskriptif karakteristik, paparan langsung dan perilaku pekerja selengkapnya dijelaskakan pada Tabel 2.

Hasil analisis bivariat menggunakan uji Mann Whitney menunjukkan bahwa konsentrasi paraquat dalam urin pekerja dipengaruhi oleh beberapa variabel yaitu lama kerja $(\mathrm{p}=0,026)$, metode penyemprotan $(p=0,048)$, makan/minum saat aplikasi $(\mathrm{p}=0,040)$, kelengkapan penggunaan alat pelindung diri $(\mathrm{p}=0,03)$ dan dekontaminasi setelah terpapar paraquat $(\mathrm{p}=0,026)$. Data analisis bivariat selengkapnya dapat dilihat pada Tabel 3.

\section{PEMBAHASAN}

Konsentrasi paraquat dalam tubuh pekerja sangat bervariasi, kondisi ini karena kemampuan tubuh seseorang untuk mendetoksifikasi bahan kimia yang masuk dalam tubuh dan sistem imunitas setiap individu berbeda. ${ }^{33}$ Selain itu, waktu paruh eliminasi paraquat melalui urin sangat singkat yaitu antara 5-84 jam dan juga bisa dari 6 jam sampai 4 hari. ${ }^{34}$ Meskipun waktu paruh paraquat dalam urin sangat singkat, tetapi paraquat yang terabsorpsi melalui rute ingesti, inhalasi dan dermal selanjutnya didistribusikan ke seluruh bagian tubuh dan terdeposit dalam paru-paru, hati dan ginjal. ${ }^{21}$

Studi di perkebunan kopi konsentrasi paraquat dalam urin ditemukan rata-rata $5,74 \mathrm{mg} / \mathrm{L}$; di perkebunan pisang sebesar $11,39 \mathrm{mg} / \mathrm{L}$; di perkebunan kelapa sawit sebesar $2,19 \mathrm{mg} / \mathrm{L} ;{ }^{26}$ diperke-

Tabel 1.Hasil Pemeriksaan Konsentrasi Paraquat dalam Urin Pekerja $(n=60)$

\begin{tabular}{lccc}
\hline \multicolumn{1}{c}{ Variabel } & Satuan & Median & Minimum - Maksimum \\
\hline Jenis kelamin & & & \\
$\quad$ Pria $(\mathrm{n}=23)$ & $\mathrm{mg} / \mathrm{L}$ & 3,09 & $0,25-27,39$ \\
$\quad$ Wanita $(\mathrm{n}=37)$ & & 3,78 & $0,25-35,75$ \\
Aktivitas Pekerjaan & $\mathrm{mg} / \mathrm{L}$ & 3,98 & $0,25-35,75$ \\
$\quad$ Penyemprot $(\mathrm{n}=45)$ & & 2,86 & $0,25-23,26$ \\
$\quad$ Pengawas $(\mathrm{n}=15)$ & &
\end{tabular}


Tabel 2. Karakteristik Pekerja, Paparan Langsung dan Perilaku Pekerja

\begin{tabular}{|c|c|c|}
\hline Variabel & $\mathrm{n}=60$ & $\%$ \\
\hline \multicolumn{3}{|l|}{ 1. Karakteristik Responden } \\
\hline \multicolumn{3}{|l|}{ Umur } \\
\hline$\geq 34$ tahun & 37 & 61,7 \\
\hline$<34$ tahun & 23 & 38,3 \\
\hline \multicolumn{3}{|l|}{ Jenis Kelamin } \\
\hline Pria & 23 & 38,3 \\
\hline Wanita & 37 & 61,7 \\
\hline \multicolumn{3}{|l|}{ Tingkat Pendidikan } \\
\hline Rendah (SD,SMP) & 43 & 71,7 \\
\hline Tinggi (diatas SMA) & 17 & 28,3 \\
\hline \multicolumn{3}{|l|}{ Masa Kerja } \\
\hline$\geq 2$ tahun & 33 & 55 \\
\hline$<2$ tahun & 27 & 45 \\
\hline \multicolumn{3}{|l|}{ Indeks Masa Tubuh } \\
\hline$\geq 22,9 \mathrm{~kg} / \mathrm{m}^{2}$ & 26 & 26 \\
\hline$<22,9 \mathrm{~kg} / \mathrm{m}^{2}$ & 34 & 74 \\
\hline \multicolumn{3}{|l|}{ 2. Paparan Langsung } \\
\hline \multicolumn{3}{|l|}{ Lama Kerja } \\
\hline$\geq 5$ jam & 36 & 60 \\
\hline$<5 \mathrm{jam}$ & 24 & 40 \\
\hline \multicolumn{3}{|l|}{ Aktivitas Pekerja } \\
\hline Penyemprot & 45 & 75 \\
\hline Pengawas & 15 & 25 \\
\hline \multicolumn{3}{|c|}{ Kontak tubuh selama penyemprotan } \\
\hline Ya & 57 & 95 \\
\hline Tidak & 3 & 5 \\
\hline \multicolumn{3}{|l|}{ Metode Penyemprotan } \\
\hline Mengikuti arah angin & 38 & 63,3 \\
\hline Tidak mengikuti arah angin & 22 & 36,7 \\
\hline \multicolumn{3}{|l|}{ Makan/Minum saat aplikasi } \\
\hline Ya & 37 & 61,7 \\
\hline Tidak & 23 & 38,3 \\
\hline \multicolumn{3}{|l|}{ 3. Perilaku Pekerja } \\
\hline \multicolumn{3}{|l|}{ Kebiasaan Merokok } \\
\hline Ya & 14 & 23,3 \\
\hline Tidak & 46 & 76,7 \\
\hline \multicolumn{3}{|l|}{ Kelengkapan Alat Pelindung Diri } \\
\hline Tidak lengkap & 35 & 58,3 \\
\hline Lengkap & 25 & 41,7 \\
\hline \multicolumn{3}{|l|}{ Dekontaminasi setelah terpapar } \\
\hline Ya & 36 & 60 \\
\hline Tidak & 24 & 40 \\
\hline
\end{tabular}

bunan pisang ditemukan sebesar $<0,03 \mathrm{mg} / \mathrm{L}$ dan $0,24 \mathrm{mg} / \mathrm{L} \cdot{ }^{27}$ di Sri Lanka ditemukan antara $<0,1-0,37 \mu \mathrm{g} / \mathrm{mL} ;{ }^{28}$ di Amerika Serikat pekerja aplikasi paraquat lebih dari 12 minggu konsentrasi paraquat dalam urin ditemukan antara $0,15-0,32$ $\mathrm{mg} / \mathrm{L} .{ }^{29}$ Selain itu, konsentrasi paraquat dalam urin juga ditemukan pada ibu yang tinggal disekitar area pertanian Thailand, yaitu pada ibu dengan kehamilan 28 minggu, ibu bersalin dan 2 bulan setelah melahirkan masing-masing adalah 2,04, 2,06 dan $2,42 \mathrm{ng} / \mathrm{mL} .{ }^{30}$ Meskipun sampai saat ini parameter paraquat dalam urin belum ditetapkan 
Tabel 3. Hasil Analisis Bivariat Perbedaan Konsentrasi Paraquat dalam Urin Pekerja

\begin{tabular}{|c|c|c|}
\hline Variabel & $n=60$ & p value \\
\hline \multicolumn{3}{|l|}{ 1. Karakteristik Responden } \\
\hline \multicolumn{3}{|l|}{ Umur } \\
\hline$\geq 34$ tahun & 37 & 0,584 \\
\hline$<34$ tahun & 23 & \\
\hline \multicolumn{3}{|l|}{ Jenis Kelamin } \\
\hline Pria & 23 & 0,970 \\
\hline Wanita & 37 & \\
\hline \multicolumn{3}{|l|}{ Tingkat Pendidikan } \\
\hline Rendah (SD,SMP) & 43 & 0,231 \\
\hline Tinggi (diatas SMA) & 17 & \\
\hline \multicolumn{3}{|l|}{ Masa Kerja } \\
\hline$\geq 2$ tahun & 33 & 0,384 \\
\hline$<2$ tahun & 27 & \\
\hline \multicolumn{3}{|l|}{ Indeks Masa Tubuh } \\
\hline$\geq 22,9 \mathrm{~kg} / \mathrm{m}^{2}$ & 26 & 0,221 \\
\hline$<22,9 \mathrm{~kg} / \mathrm{m}^{2}$ & 34 & \\
\hline \multicolumn{3}{|l|}{ 2. Paparan Langsung } \\
\hline \multicolumn{3}{|l|}{ Lama Kerja } \\
\hline$\geq 5$ jam & 36 & $0,026^{*}$ \\
\hline$<5$ jam & 24 & \\
\hline \multicolumn{3}{|l|}{ Aktivitas Pekerja } \\
\hline Penyemprot & 45 & 0,638 \\
\hline Pengawas & 15 & \\
\hline \multicolumn{3}{|c|}{ Kontak tubuh selama penyemprotan } \\
\hline $\mathrm{Ya}$ & 57 & 0,308 \\
\hline Tidak & 3 & \\
\hline \multicolumn{3}{|l|}{ Metode Penyemprotan } \\
\hline Mengikuti arah angin & 38 & $0,048^{*}$ \\
\hline Tidak mengikuti arah angin & 22 & \\
\hline \multicolumn{3}{|l|}{ Makan/Minum saat aplikasi } \\
\hline Ya & 37 & $0,040^{*}$ \\
\hline Tidak & 23 & \\
\hline \multirow{2}{*}{\multicolumn{3}{|c|}{$\begin{array}{l}\text { 3. Perilaku Pekerja } \\
\text { Kebiasaan Merokok }\end{array}$}} \\
\hline & & \\
\hline $\mathrm{Ya}$ & 14 & 0,517 \\
\hline Tidak & 46 & \\
\hline \multicolumn{3}{|l|}{ Kelengkapan Alat Pelindung Diri } \\
\hline Tidak lengkap & 35 & $0,030^{*}$ \\
\hline Lengkap & 25 & \\
\hline \multicolumn{3}{|l|}{ Dekontaminasi setelah terpapar } \\
\hline $\mathrm{Ya}$ & 36 & $0,026^{*}$ \\
\hline Tidak & 24 & \\
\hline
\end{tabular}

*Uji Mann Whitney

baik secara nasional maupun internasional, keberadaan paraquat dalam tubuh pekerja sangatlah berbahaya baik dalam waktu yang singkat maupun apalagi paparan jangka panjang. Kondisi ini dapat menimbulkan gangguan kesehatan bahkan penyakit akibat kerja.
Konsentrasi paraquat dalam urin pekerja berumur $\geq 34$ tahun lebih tinggi dibandingkan umur $<34$ tahun, walaupun secara statistik tidak ada perbedaan antara kelompok umur dengan paraquat dalam urin. Namun umur, berkaitan dengan kekebalan tubuh seseorang dalam mengatasi 
tingkat toksisitas suatu zat termasuk paraquat, semakin tua umur seseorang maka efektifitas sistem kekebalan di dalam tubuh akan semakin berkurang. ${ }^{37}$ Umur merupakan salah satu faktor karakteristik pekerja yang secara tidak langsung mempengaruhi efek paraquat dalam tubuh pekerja. Hal ini karena semakin bertambah umur pekerja maka semakin lama pekerja tersebut terpapar dengan paraquat, sehingga jumlah paraquat yang terabsorpsi masuk ke dalam tubuh lebih banyak.

Konsentrasi paraquat dalam urin pekerja wanita lebih tinggi dibandingkan pria, walaupun tidak ada perbedaan antara jenis kelamin dengan konsentrasi paraquat dalam urin. Namun, perbedaan konsentrasi paraquat dalam urin pekerja ditentukan oleh sistem imunitas seseorang, secara fisiologis tubuh mempunyai kemampuan untuk melawan hampir semua jenis mikroorganisme atau toksin termasuk bahan kimia yang cenderung merusak organ tubuh; kemampuan setiap individu untuk mendetoksifikasi bahan kimia yang diabsopsi tubuh juga berbeda. ${ }^{33}$ Selain itu hasil wawancara dengan pekerja wanita diperoleh bahwa pekerja wanita saat pulang ke rumah tidak langsung membersihkan tubuh, tetapi mengerjakan pekerjaan rumah, hal ini menyebabkan sisa-sisa residu paraquat menempat pada tubuh pekerja.

Konsentrasi paraquat dalam urin pekerja yang berpendidikan rendah lebih tinggi dibandingkan dengan yang berpendidikan tinggi, meskipun secara statistik tidak ada perbedaan yang signifikan. Tingkat pendidikan merupakan salah satu faktor karaketristik individu yang secara tidak langsung mempengaruh konsentrasi paraquat dalam urin. Meskipun kenyataan menunjukkan tidak ada perbedaan antara tingkat pendidikan dengan konsentrasi paraquat dalam urin, tetapi tingkat pendidikan rendah lebih memungkinkan pekerja untuk mengalami paparan paraquat selama penyemprotan karena pekerja kurang memahami tentang bahaya akibat paparan paraquat.

Konsentrasi paraquat dalam urin pekerja dengan masa kerja $\geq 2$ tahun lebih tinggi, meskipun tidak ada perbedaan antara masa kerja dengan konsentrasi paraquat dalam urin. Namun, masa kerja yang lebih lama menyebabkan seorang pekerja akan lebih lama terpapar dengan paraquat. Hal ini menyebabkan paraquat yang diaplikasikan saat penyemprotan lebih banyak terabsorpsi ke dalam tubuh pekerja melalui rute inhalasi, ingesti dan kulit. ${ }^{21}$

Konsentrasi paraquat dalam urin pekerja dengan Indeks Masa Tubuh $\geq 22,9 \mathrm{~kg} / \mathrm{m}^{2}$ lebih tinggi dibandingkan dengan indeks masa tubuh $<22,9$ $\mathrm{kg} / \mathrm{m}^{2}$. Meskipun kenyataan menunjukkan bahwa tidak ada perbedaan antara indeks masa tubuh dengan konsentrasi paraquat dalam urin, tetapi indeks masa tubuh merupakan gambaran status gizi pekerja. Hal ini karena pekerja mempunyai status gizi baik atau normal, sehingga pekerja cenderung mempunyai daya tahan tubuh yang baik. Selain itu, orang yang sehat lebih tahan terhadap bahan kimia termasuk paraquat yang terabsorpsi ke dalam tubuh. ${ }^{33}$

Konsentrasi paraquat dalam urin ditemukan lebih tinggi pada pekerja yang melakukan aplikasi $\geq 5$ jam/hari, kenyataan ini menunjukkan terdapat perbedaan antara lama kerja dengan konsentrasi paraquat dalam urin. Kondisi ini menyebabkan waktu keterpaparan pekerja dengan paraquat lebih lama sehingga jumlah dosis potensial paraquat melalui rute inhalasi dan kulit semakin tinggi. Waktu kerja yang digunakan pekerja untuk melakukan aplikasi penyemprotan melebihi waktu yang direkomendasikan dimana seorang pekerja hanya diperbolehkan melakukan penyemprotan 4-5 jam/hari. ${ }^{38}$

Konsentrasi paraquat dalam urin ditemukan lebih tinggi pada pekerja penyemprot dibandingkan pengawas. Meskipun kenyataan menunjukkan bahwa tidak ada perbedaan antara aktivitas pekerjaan dengan konsentrasi paraquat dalam urin, tetapi keterpaparan paraquat paling sering yaitu pada pekerja yang melakukan aplikasi penyemprotan. ${ }^{7}$ Kondisi ini disebabkan karena penyemprot terpapar langsung dengan paraquat selama aplikasi penyemprotan di area perkebunan sawit.

Konsentrasi paraquat dalam urin pekerja yang kontak tubuh saat bekerja lebih tinggi, tetapi tidak ada perbedaan antara kontak tubuh selama penyemprotan dengan konsentrasi paraquat dalam urin. Kontak tubuh akibat tumpahan atau percikan droplet paraquat saat aplikasi penyemprotan merupakan hal yang paling sering dialami pekerja. Hal ini mengakibatkan paraquat dapat terabsorpsi melalui membran tubuh melalui gastro intestinal, paru-paru dan kulit. ${ }^{39}$ Kontak tubuh dengan paraquat melalui kulit lebih sering terjadi disebabkan 
alat pelindung diri yang digunakan kurang memadai seperti sarung tangan yang digunakan terbuat dari kain yang dengan mudah menyerap paraquat saat aplikasi.

Saat melakukan penyemprotan pekerja mayoritas tidak memperhatikan arah angin, hal ini menyebabkan konsentrasi paraquat dalam urin lebih tinggi. Kondisi ini menyebabkan jumlah konsentrasi paraquat yang disemprotkan lebih banyak terhirup oleh pekerja melalui rute inhalasi. Meskipun dalam pedoman pembinaan penggunaan pestisida telah ditentukan bahwa saat aplikasi tidak diperbolehkan berjalan berlawanan dengan arah angin dan tidak melalui area yang telah di aplikasi. ${ }^{38}$ Kenyataan menunjukkan bahwa masih banyak pekerja saat aplikasi penyemprotan tidak memperhatikan arah angin, hal ini karena pekerja tidak mengetahui bahaya dan efek kesehatan yang ditimbulkan akibat kondisi tersebut. Hasil penelitian di perkebunan sawit Kabupaten Banyuasin pada pekerja yang tepapar paraquat dilaporkan bahwa dosis potensial paraquat yang masuk dalam tubuh melalui rute inhalasi sebesar $0,001 \mathrm{mg} /$ $\mathrm{kg} / \mathrm{hr}{ }^{23}$ dan di perkebunan Malaysia dosis potensial ditemukan sebesar $0,025 \mathrm{mg} / \mathrm{kg} / \mathrm{hr},{ }^{24}$ nilai ini melebihi batas aman yang telah ditetapkan Acceptable Operator Exposure Limit (AOEL $=0,0005$ $\mathrm{mg} / \mathrm{kg} /$ day) ${ }^{40}$

Mayoritas pekerja melakukan makan/ minum saat aplikasi penyemprotan paraquat, hal ini menyebabkan paraquat masuk ke dalam tubuh pekerja pada saat makan/minum. Meskipun dalam pedoman Peraturan Kementerian Pertanian telah dilarang pekerja untuk menyentuh mulut/hidung saat aplikasi dan makan/minum di area aplikasi penyemprotan. ${ }^{38}$ Kenyataannya bahwa saat istirahat dan penyemprotan pekerja melakukan makan/ minum di area penyemprotan, hal ini disebabkan tidak tersedianya tempat istirahat untuk makan/ minum bagi pekerja. Kondisi ini memudahkan paraquat masuk ke dalam tubuh pekerja pada saat makan/minum.

Konsentrasi paraquat dalam urin pekerja yang tidak merokok lebih tinggi, hal ini karena mayoritas pekerja adalah wanita dan tidak merokok, hasil penelitian menunjukkan bahwa konsentrasi paraquat lebih tinggi pada wanita. Kondisi ini yang menyebabkan konsentrasi pada pekerja wanita yang tidak merokok tinggi. Meskipun te- lah ada larangan bagi pekerja untuk tidak merokok selama melakukan aplikasi penyemprotan pestisida, ${ }^{38}$ tetapi masih banyak pekerja terutama pekerja pria merokok saat penyemprotan. Kondisi ini tanpa disadari pekerja dapat menyebabkan paraquat terabsorbsi ke dalam tubuh pekerja melalui hisapan rokok.

Konsentrasi paraquat dalam urin pekerja yang menggunakan alat pelindung diri tidak lengkap lebih tinggi dibandingkan yang menggunakan alat pelindung diri secara lengkap. Hal ini disebabkan saat menggunakan alat pelindung diri pekerja merasa panas dan tidak nyaman dan ketersediaan alat pelindung diri sangat terbatas di perusahaan. Hasil studi pada petani di Mesir dilaporkan bahwa 95\% petani tidak melakukan tindakan keselamatan selama penyemprotan pestisida ${ }^{41}$ bahkan di Brazil mayoritas petani tidak menggunakan alat pelindung diri. ${ }^{42}$

Konsentrasi paraquat dalam urin pekerja yang tidak melakukan dekontaminasi setelah terpapar paraquat lebih tinggi dibandingkan yang melakukan dekontaminasi. Dekontaminasi adalah membersihkan tubuh setelah penggunaan pestisida baik setelah penyemprotan maupun pencampuran/ pengadukan. Kondisi ini menyebabkan sisa-sisa paraquat setelah aplikasi penyemprotan menempel pada kulit dan pakaian pekerja, akibatnya paraquat dapat terabsorbsi melalui kulit inhalasi terakumulasi dalam tubuh atau terdeposit dalam target organ. ${ }^{21}$ Studi di Nepal dilaporkan bahwa sekitar $52 \%$ wanita dan $42 \%$ pria tidak mencuci tangan/ membersihkan tubuh setelah menyemprot pestisida. ${ }^{43}$ Namun meskipun pekerja melakukan dekontaminasi setelah terpapar paraquat hanya mencuci tangan menggunakan air yang ada di sekitar area penyemprotan bukan di ruangan khusus yang disediakan perusahaan. Kondisi ini karena tidak tersedianya tempat khusus untuk membersihkan tubuh saat pekerja selasai melakukan aplikasi paraquat.

\section{KESIMPULAN DAN SARAN}

Penelitian ini menemukan keberadaan konsentrasi paraquat dalam urin pekerja yang melakukan penyemprotan di perkebunan kelapa sawit. Fakta ini menunjukkan bahwa paraquat yang terakumulasi dalam tubuh pekerja meskipun dieliminasi melalui urin tetapi residu paraquat akan tetap ada dalam tubuh pekerja. Konsentrasi 
paraquat dalam urin pekerja dipengaruhi beberapa variabel yaitu lama kerja, metode penyemprotan, makan/minum saat penyemprotan, kelengkapan penggunaan alat pelindung diri dan dekontaminasi setelah terpapar paraquat.

Bagi perusahaan agar menyediakan alat pelindung diri secara lengkap dan sesuai standar dan memberikan sanksi bagi pekerja yang tidak menggunakan pelindung diri secara lengkap, serta kegiatan biomonitoring dilakukan secara berkala bagi pekerja. Bagi pemerintah agar ditetapkan standar indeks pemantauan biologi untuk konsentrasi paraquat dalam urin sebagai acuan untuk membandingkan nilai batas aman konsentrasi pestisida dalam tubuh.

\section{UCAPAN TERIMA KASIH}

Ucapan terima kasih disampaikan kepada Lembaga Pengelola Dana Pendidikan (LPDP) Kementerian Keuangan yang telah membantu biaya pemeriksaan laboratorium, pihak manajemen dan staf perkebunan kelapa sawit di Kabupaten Banyuasin, mahasiswa DIII Keperawatan Palembang yang terlibat dalam pengumpulan data.

\section{DAFTAR PUSTAKA}

1. Kementerian Pertanian Republik Indonesia. Pestisida Pertanian dan Kehutanan Terdaftar. Ditjen Prasarana \& Produksi Pertanian; 2016.

2. Qian H, Wei C, Liwei S, Yuanxiang J, Zhengwei F. Inhibitory effects of Paraquat on photosinthesis and the response in Chlorella vulgaris. Ecotoxicology, 2009;18:537-543.

3. Soenardjo. Isolasi dan Karakterisasi Bakteri Karang Pendegradasi Senyawa Herbisida Paraquat di Perairan Pantai Teluk Awur Jepara. Universitas Diponegoro, Semarang; 2004.

4. World Health Organization. The WHO Recommended Classification of Pesticides by Hazard and Guidelines to Classification. Geneva; 2009.

5. Watts M. Paraquat. PANAP (Pesticide Action Network Asia \& Pacifik); 2011.

6. Permentan, RI. Nomor 01 tentang Daftar Bahan Aktif Pestisida Dilarang dan Terbatas. Jakarta;2007.

7. Djojosumarto. Teknik Aplikasi Pestisida Pertanian. Yogyakarta, Kanisius; 2008.
8. Banday T.H., Bashir S, Bhat Shasikant, K Ashwin, Praveen S.G., Jagadees. Manifestation and Management of Paraquat Intoxication. A Deadly Poison. IOSDR. Journal of Dental and Medical Sciences. 2014;12(6):74-76.

9. Kervegant M., Merigot L., Glaizal M., Schmitt C., TichadouL., HaroL. Paraquat Poisonings in France during the European Ban Experience of the Poison Control Center in Marseille. J. Med. Toxicol. 2013;9:144-147.

10. Hwang K.Y., Lee E.Y., Hong S.Y., Paraquat Intoxication in Korea, Archives of Environmental Health. 2002;162-166.

11. Landrigan PJ., and Claudio L. Pestisida, Environmental Toxicants, Third Edition Edited by Morton Lippmann; 2009.

12. Hancock D.B., Martin E.R., Mayhew G.M., Stajich J. M., Jewett R, Stacy M.A., ScottB.L., Vance J.M., Scott WK. Pesticide exposure and risk of Parkinson'sdisease : A familybased case-control study. BMC Neurology, 2008;8(6):1-12.

13. Cory-Slechta D.A., Thiruchelvam M., Barlow B.K., Richfield E. K. Developmental Pesticide Models of the Parkinson Disease Phenotype. Environ. Health Perspective. 2005; 113(9):1263-1270.

14. Changbin Du. Paraquat, Toxicity and Mechanism. Department of Radiation Oncology The University of Lowa; 2005.

15. Gawarammana B.I., and Buckley A. N. Medical Management of Paraquat Ingestion. British Journal of Pharmacology, 2010;72(5) :745-757.

16. Costello S, Cockburn M, Bronstein J, Zhang $\mathrm{X}$, and Ritz B,. Parkinson's Disease and Residential Exposure to Maneb and Paraquat Fromagricultural Applications in the Central Valley of California. American Journal of Epidemiology. 2009;169(8):919-926.

17. Li Z, Dong T, Proschel C, Noble M. Chemically Diverse Toxicantsconverge on Fyn and c-Cbl to Disrupt Precursor Cell Function. PLOS Biologi. 2007;5(2):0212-0231.

18. Kang MJ., GilSJ., KohHC. Paraquat Induces Alternation of Thedopamine Catabolic Pathways and Glutathione Levels in the Substantia Nigraof Mice. Toxicol Lett. 2009;188:148152. 
19. Chen Q., Niu Y., Zhang R., Guo H., Gao Y., Li Y., Liu R. The Toxicinfuence of Paraquat on Hippocampus of Mice: Involvement of Oxidativestress. Neurotoxicol. 2010;31(3):310-316.

20. Lock E.A., and Wilks M.F. Paraquat. in: Krieger RI (ed.), Hayes' Handbook of Pesticide Toxicology (3.ed.),. Elsevier Inc.2010;1767-1823,

21. Centers for Disease Control (CDC). Fact about Paraquat; 2003.

22. Maksuk, Malaka T, Suheryanto, Umayah A. Environmental Health Risk Analysis of Paraquat Exposure in Palm Oil Plantations. International Journal of Public Health Science (IJPHS). 2016;5(4):465-469.

23. Maksuk, Malaka T, Suheryanto, Umayah A. Risk Quotient of Airborne Paraquat Exposure among Workers in Palm Oil Plantation, International Journal of Public Health Science (IJPHS). 2018;7(2):97-101. DOI: 10.11591/ ijphs.v7i2.pp97-101.

24. Morshed MM, Omar D, Mohammad R, Wahed S \& Rahman MA., "Airborne Paraquat Measurement and Its Exposure in Treated Field Environment". International Journal of Agriculture \& Biology. 2010;12:679-684.

25. Dinis-Oliveira R.J., Duarte J.A. Paraquat Poisonings: Mechanisms of Lung Toxicity, Clinical Features and Treatment. Critical Review Toxicology. 2008;38:13-71.

26. Lee K, ParkE.K., Marois M.S., Marja E.K., Gee S.J., Hammock B.D., Beckett L.A., Schenker M.B. Occupational Paraquat Exposure of Agricultural Workers in Large Costa Rican Farms. Int Arch Occup Environ Health. 2009;82:455-462.

27. van Wendel De Joode B.N., De Graaf Inge A.N., Wesseling C, Kromhout H. Paraquat Exposure of Knapsack Spray Operators on Banana Plantations in Costa Rica. International Journal Occupational Environmental Health. 1996;2(4):294-304.

28. Chester G, Gurunathan G, Jones N, Woolen B.H. Occupational Exposure of Sri Lankan Tea Plantation Workers to Paraquat. Bulletin WHO. 1993;71:625-32.

29. Baselt R.C., \& Cravey R.H. Paraquat In: Disposition of Toxic Drugs and Chemicals in Man. $3^{\text {rd }}$ ed, Chicago; 1989,637-640.

30. Konthonbut P, Kongtip P, Nankongnab N,
Tipayamongkholgul, Yoosook W, Woskie S. Paraquat Exposure of Pregnant Women and Neonates in Agricultural Areas in Thailand. Int. J. Environ. Res. Public Health. 2018;15(6), 1163. https://doi.org/10.3390/ijerph15061163.

31. Dahlan S. Besar Sampel dan Cara Pengambilan Sampel dalam Penelitian Kedokteran dan Kesehatan, Edisi 3 cetakan 2. Jakarta: Salemba Medika; 2012.

32. Dahlan S. Statistik untuk Kedokteran dan Kesehatan: Deskriptif, Bivariat, dan Multivariat, Edisi 5 cetakan 3. Jakarta: Salemba Medika;2013.

33. Guyton A.C.,\& Hall J.E. Text Book of Medical Physiology. $11^{\text {th }}$ ed. Copy Right by Elsevier Inc; 2006

34. Ekwall B, Clemedson C, Crafoord B, Hallander S, Walum E, Bondesson I. MEIC Evaluation of Acute Systemic Toxicity. Part V. Rodent and Human Toxicity Data for the 50 Reference Chemicals. ATLA 26;1998:571616.

35. Houze P, Baud FJ, Mouy R, Bismuth C, Bourdon R, Scherrmann JM.. Toxicokinetics of Paraquat in Humans. Hum Exp Toxicol. 1990;9(1):5-12.

36. Wojeck G.A, Price JF, Nigge HN, Stamper $\mathrm{JH}$. Worker Exposure to Paraquat and Diquat. Arch Environ Contam Toxicol. 1983;12:6570.

37. Sembel D.T. Toksikologi Lingkungan Dampak Pencemaran dari Berbagai Bahan Kimia dalam Kehidupan Sehari-hari. Yogyakarta; 2015.

38. Kementerian Pertanian RI. Pedoman Penggunaan Pestisida Pertanian. Direktorat Sarana dan Prasarana Pertanian. Jakarta; 2011

39. Rozman K.K.,\& C.D., Klaasen. Absorption, Distribution, and Excretion of Toxicants. in Casarett \& Doull's Essentilas of Toxicology. Ed. By CD Klaasen and JB Watkins III; 2003.

40. European Commission (EC). Review Report for the Active Substance Paraquat. Health \& Consumer Protection Directorate-General, European Commission,Brussels; 2003.

41. Tchounwou P. B. Health Risk Assessment of Pesticide Usage in Menia El-Kamh Province of Sharkia Governorate in Egypt. Environmental Toxicology. 2002;1082-1094. 
42. Oliveira P.J. Knowledge, Attitudes, Practices and Biomonitoring of Farmers and Residents Exposed to Pesticides in Brazil. International Journal of Environmental Research and Public Health. 2012;9(9):3051-3068.
43. Kishor Atreya. Pesticide Use Knowledge and Practices: A Gender Differences in Nepal. Environmental Research. 2007;104(2):305311. 